\title{
8. SEAMARC II SONAR IMAGERY AND BATHYMETRY OF THE NAZCA PLATE AND PERU FOREARC, ODP LEG $112^{1}$
}

\author{
Donald M. Hussong, ${ }^{2}$ Thomas B. Reed IV, ${ }^{3}$ and Wade A. Bartlett ${ }^{3}$
}

\section{INTRODUCTION}

In March 1985, SeaMARC II side-scanning sonar and swathbathymetry surveys were conducted on the submarine Peru forearc as part of the studies to select drilling sites for Leg 112 of the Ocean Drilling Program. Most of these surveys were concentrated in two areas: (1) between $8^{\circ} 45^{\prime} \mathrm{S}$ and $9^{\circ} 35^{\prime} \mathrm{S}$, which is north of where the Mendana Fracture Zone (MFZ) enters the Peru-Chile Trench, and (2) between $11^{\circ} 00^{\prime} \mathrm{S}$ and $11^{\circ} 50^{\prime} \mathrm{S}$, on the southern side of the MFZ/trench intersection (Fig. 1). Both surveys extended from the Nazca Plate across the trench axis to the upper continental slope. We refer to the northern survey area (which includes Sites 683 and 685) as the Yaquina Basin survey and to the southern survey area (including Sites 682 and 688 ) as the Lima Basin survey.

SeaMARC II is a $12-\mathrm{kHz}$, towed sonar array that produces a long-range, side-scanning image, while simultaneously measuring bathymetric depths within the ensonified swath. The system typically is towed at speeds of about $7 \mathrm{kt}$ at a depth of about $100 \mathrm{~m}$ and can map in any ocean depth. A more complete description can be found in Blackinton et al. (1983) and Hussong and Fryer (1983). For the site-selection surveys, the SeaMARC II was set to produce an acoustic back-scatter (side-scanning) image that was a constant $10 \mathrm{~km}$ wide and that measured bathymetry in a swath at least three times as wide as the water depth. The acoustic-image data are composed of 1024 pixels (picture elements) per side per ping. Each pixel in the resulting image represents $5 \mathrm{~m}$ of seafloor across the track. These backscatter magnitude data are displayed with stronger returns in darker shades of gray. Thus, low back-scatter regions such as sediments are very light, while strong returns from reflectors such as outcropping rock are represented by dark areas. As the wavelength of the $12-\mathrm{kHz}$ signal is approximately $12 \mathrm{~cm}$ in water, the character of the side-scanning image is particularly sensitive to reflectivity changes caused by back scatter from seafloor relief on the order of $10 \mathrm{~cm}$. However, recognition of seafloor patterns is a function of the shape of the features causing the echoes. Typically, linear features (such as faults and debrisflow channels) are recognizable, even with dimensions of only a few to several tens of meters. Three-dimensional features, such as small mounds or sediment ponds, must have dimensions on the order of $100 \mathrm{~m}$ or more before a shape can be recognized.

SeaMARC II bathymetry is determined by measuring the phase angle of echoes returning to arrays of sonar receivers in the towed body. These data produce hundreds of independently determined soundings for each ping. The ping repetition rate is 8 to $11 \mathrm{~s}$ during these surveys, which are subsequently smoothed to produce swath bathymetry having $100 \%$ coverage. The accuracy of the bathymetry data during these surveys was about 50

\footnotetext{
${ }^{1}$ Suess, E., von Huene, R., et al., 1988. Proc. ODP, Init. Repts. , 112: College Station, TX (Ocean Drilling Program).

2 Seafloor Surveys International, Inc., 1221 Kapiolani Blvd. (PH-40), Honolulu, HI 95814.

${ }^{3}$ Hawaii Institute of Geophysics, 2525 Correa Rd., Honolulu, HI 96822.
}

to $100 \mathrm{~m}$, depending on water depth and local bottom conditions.

SeaMARC II data acquisition for each of the described surveys took about four days. All data were displayed in real time aboard the survey vessel. However, the data required additional processing for ship navigation, image enhancement, and bathymetry correction before assembly of the final mosaics. The southern survey (Lima Basin) was completed first. Processing of these data into a final data mosaic was completed aboard ship. The northern survey (Yaquina Basin) processing was completed at sea during a later cruise.

\section{LIMA BASIN SURVEY}

The SeaMARC II side-scanning mosaic and superimposed bathymetry for the Lima Basin survey are shown in Plate 1 (back pocket). To facilitate a description of this area, we prepared a generalized physiographic map that subdivides the Lima Basin into seven regions (Fig. 2). These regions were based on morphology and structure, which Hussong and Taylor (1985) described and attributed to tectonic disruption related to the subduction of the Nazca Plate. A block diagram of the Lima Basin area, using an interpretation of CDP-12 by S. Rupert and B. Taylor (pers. commun., 1987), demonstrates the relationship of the geometry of the subduction zone to seafloor morphology. From west to east, these regions are described as follows:

1. Nazca Plate. The morphology of the Nazca Plate (area 1 in Figs. 2 and 3 ) is dominated in this area by subduction-related normal faults that trend approximately $\mathrm{N} 40^{\circ} \mathrm{W}$, subparallel to the strike of the trench and offset about $10^{\circ}$ from the magnetic lineations of the Nazca Plate (T. Hilde, pers. commun., 1985). The faults offset the plate and its $100 \mathrm{~m}$ or more of sediment and have throws that vary from a few to as much as $200 \mathrm{~m}$ in this region. The faults appear as dark lineations in the sidescanning mosaic when the scarp face is oriented toward the ship's track (Plate 1). No echoes come from the scarp itself. As can be seen, the faults are continuous for many tens of kilometers.

2. Trench Axis. The turbidite-filled sediment pond (area 2 in Fig. 2), approximately defined by the $6200-\mathrm{m}$ contour in Figure 2 , is more than $8 \mathrm{~km}$ wide at the northern end of the survey area but pinches out and disappears to the south. A fault block on the Nazca Plate bifurcates this trench-fill pond at about $11^{\circ} 10^{\prime} \mathrm{S}$ to $11^{\circ} 13^{\prime} \mathrm{S}$. The turbidites that fill the trench axis are more than $300 \mathrm{~m}$ thick at its wide northern part. The surface of this trenchfill turbidite pond is essentially flat, as shown by its reflectivity in the SeaMARC II image. Locally, the pond is folded and sometimes is tilted seaward by the effects of convergence against the South American Plate.

3. Inner Trench Wall. The inner (landward) trench wall rises from 6200 to $4000 \mathrm{~m}$ in a distance of about $15 \mathrm{~km}$. This wall can be seen as area 3 in Figure 3. This inner wall has a regional slope of about $9^{\circ}$ and is composed of many narrow ledges having extensive lateral continuity. The base of this slope is composed of a narrow ledge of slightly uplifted, deformed, and often landward-tilted trench-fill sediments. We believe that this base is the 


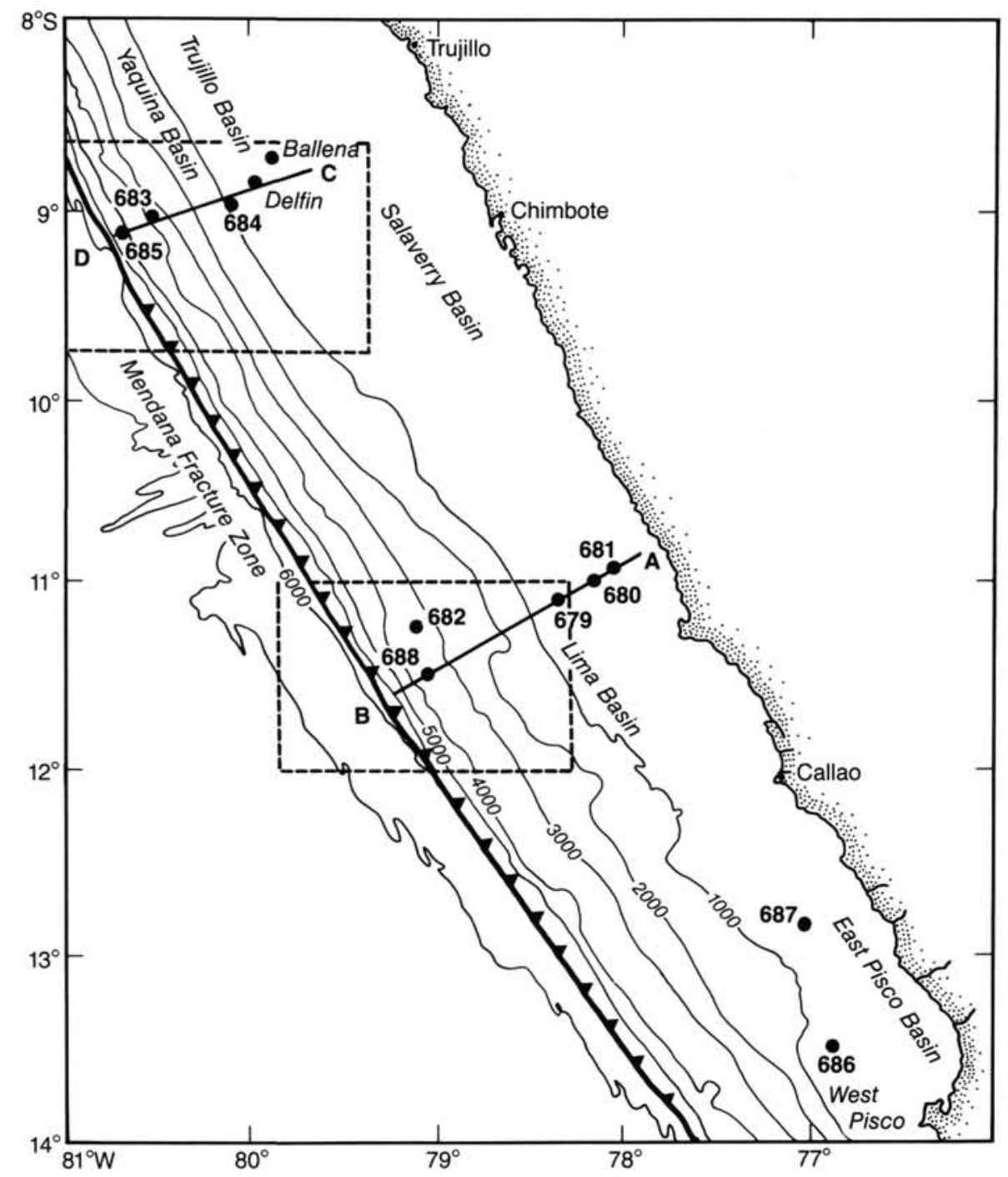

Figure 1. Location map for Leg 112 sites, Peru Continental Margin.

most active part of the deformation front of the forearc. The SeaMARC II image of inner trench wall fits the pattern of a typical accretionary complex, where packets of uplifted trenchfill sediment become older, more indurated, and less laterally continuous with elevation.

There are no signs of canyons or debris-flow channels on this part of the inner trench wall, which suggests that little sediment from the forearc enters the trench from above. Since the trenchfill turbidites pinch out to the south, the sediments in the trench (and thus the sediments in the inner trench wall) probably are derived from north of the Lima Basin survey area.

4. Midslope Basins. Deep, turbidite-filled basins extend from about 15 to $30 \mathrm{~km}$ landward of the trench axis, in water depths of 4000 to $3700 \mathrm{~m}$ (area 4 in Fig. 3). Seismic-reflection data suggest that this area is actually composed of many smaller basins of up to a few tens of kilometers in extent, each of which probably has a different vertical tectonic history. The subducting Nazca oceanic plate occurs at a depth of only about 3 to $6 \mathrm{~km}$ subbottom under the midslope basins (Hussong and Wipperman, 1981). Thus, any changes in subduction geometry (such as relief on the downgoing slab) can be expected to affect significantly the thin overriding forearc.

The side-scanning images of these midslope basins indicate that various parts of the turbidite ponds have different acoustic properties. Some areas are much lighter than other areas because of less back-scattered acoustic energy, even though there is little difference in the slope and/or the geologic nature of the seafloor. These different characteristics of the back scatter are not artifacts of the SeaMARC II measurements; the differences are independent of the look angle and angle of incidence. In some cases, the increased back scatter appears related to gentle slopes of much less than $1^{\circ}$. This increased back scatter is probably caused by small-scale increases in bottom roughness, such as ripple marks, slumping, or other types of micromorphology with amplitudes and wavelengths of a few centimeters. Therefore, it seems that the more horizontal and turbidite-covered the seafloor is, the less microrelief is revealed, and that even slight tilting generates an environment where centimeter-scaled relief can occur. Alternatively, or perhaps simultaneously, this microrelief may be a function of aging of the turbidite surfaces and long-term factors, such as bottom-current scouring.

Much of the bottom-transported sediment in the midslope basin area is topographically blocked from the inner trench wall and the trench itself by an along-strike, regional topographic high that rises to $100 \mathrm{~m}$ above the main basin. This regional high (hachured area in Fig. 2) is about $5 \mathrm{~km}$ inland from the trench-slope break at the top of the inner trench wall and appears to be uplifted by a series of high-angled thrust faults (Fig. 


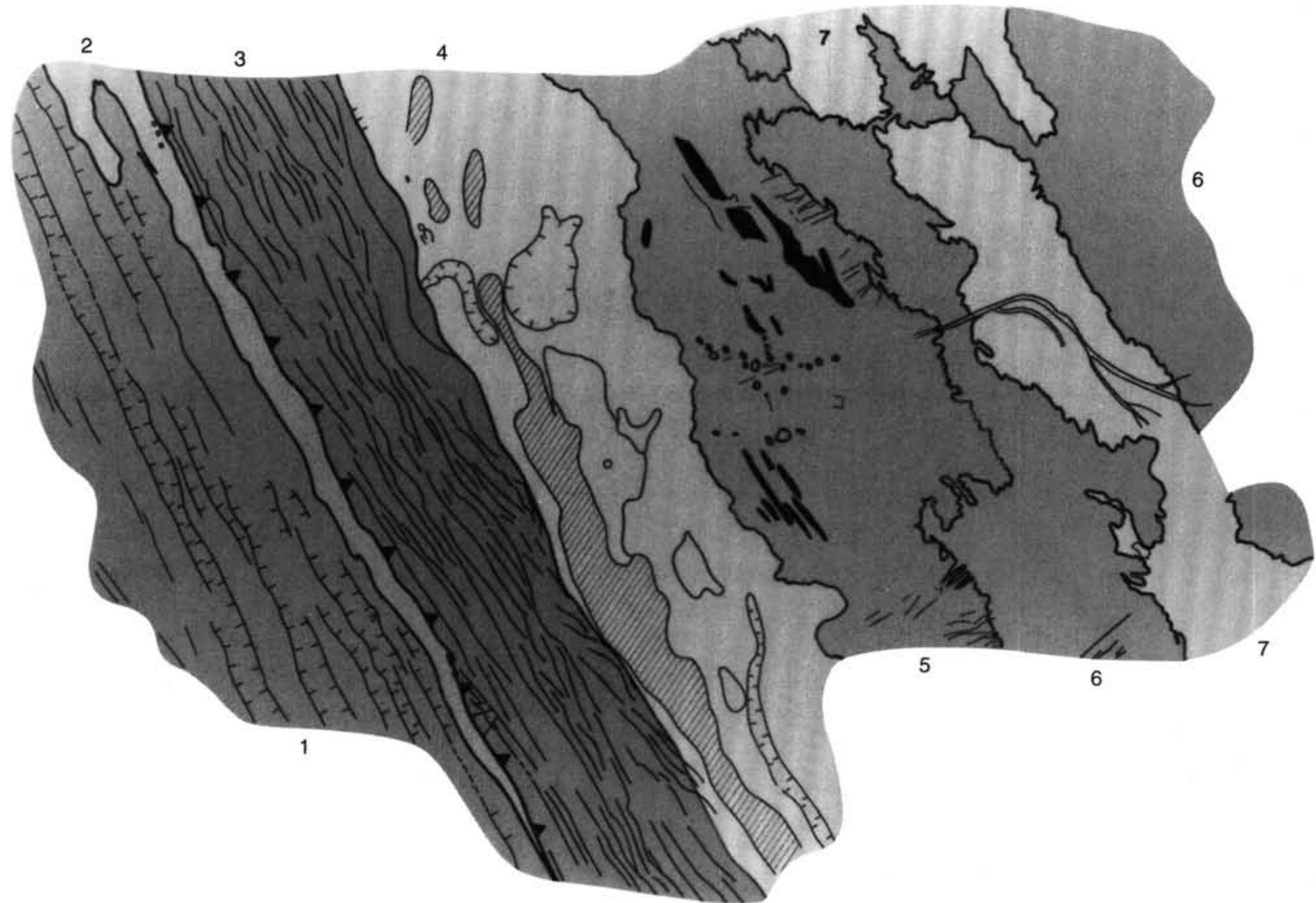

Nazca Plate

Accreted inner trench wall

lower Miocene and older exposed midslope sediments

2 Turbidite fill in trench

Figure 2. Generalized physiographic map of the Lima Basin area.

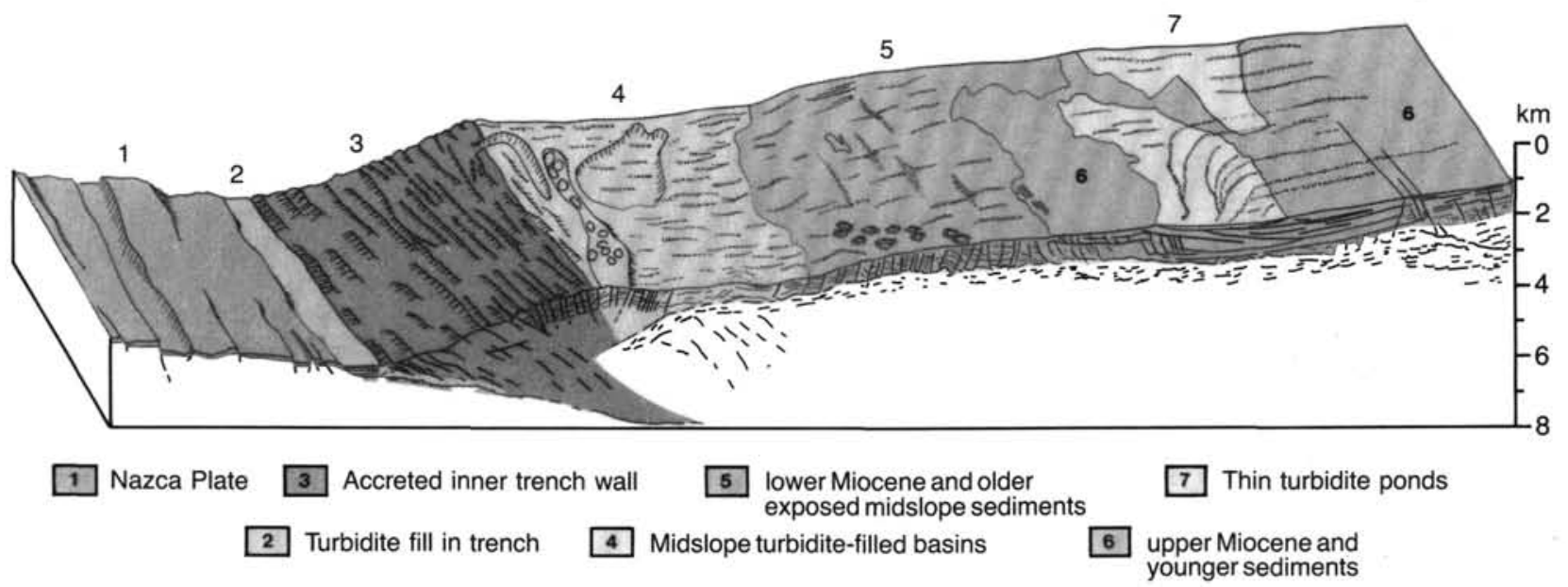

Figure 3. Block diagram of the Lima Basin area.

2). Domed, low-relief areas of low-acoustic back scatter observed on the SeaMARC II side-scanning mosaic in this area were interpreted by cruise personnel as diapiric structures, possibly with extrusive regions on the seafloor. Piston coring of some of these low domes during site surveys was unsuccessful. Thus, no direct evidence of diapiric origin was obtained.

5. Western Edge of the South American Continent. In water depths of 3600 to $2800 \mathrm{~m}$ (area 5), the seafloor has a steeper 
slope and may be dominated by erosional processes. The sidescanning image shows many debris-flow channels that trend downslope. The dark areas striking parallel to the trench were interpreted as more-lithified, outcropping sediment layers and may be the tectonically disturbed extension of basal sediments of the upper part of the eastern slope. These dark outcropping sediments form low-relief terraces. Sediments moving downslope are temporarily deposited above these outcrops in light turbidite ponds, while debris-flow channels erode the terraces and form dark gullies having occasional enlarged canyons (notably between lines $\mathrm{C}$ and D on Plate 1).

In this same depth range, a series of dark, round features trends obliquely downslope on both sides of line E. Although no samples or other direct evidence was available from this region, the side-scanning images look much like known seafloor mud volcanoes described in SeaMARC II data from other areas (Hussong, 1986). The location of these possible mud volcanoes suggests that the source of the fluids driving the extrusions may be the descending oceanic plate, which is about $6 \mathrm{~km}$ sub-bottom (Hussong and Wipperman, 1981). At these sub-bottom depths, sediments on the subducting oceanic plate may be dewatered, and the plate may also be in the initial stages of deserpentinization. Although the crystalline continental rock massif of South America was interpreted to extend even closer to the trench than this area (see Fig. 3), both refraction (increasing velocities west to east; Hussong and Wipperman, 1981) and seismic-reflection data suggest that the mud volcanoes may lie above the western edge of the unbroken continental massif at the eastern limit of deep, landward-dipping faults (Fig. 3). Thus, fluids released from the upper part of the descending oceanic plate at deeper points may migrate back up the subduction zone until they reach the first major fractures through the continental massif, where they percolate up and feed these mud volcanoes.

The bottom slopes decrease east of a water depth of $2890 \mathrm{~m}$. This upper-slope region is characterized by very dark outcropping sediments that represent the western extent of the Lima Basin (Thornburg and Kulm, 1981). These sediments were extensively sampled by Kulm et al. (1981) and described as indurated and brecciated mudstones and siltstones interspersed with relatively thin (tens of centimeters or less) dolomite lenses. The sediments were deposited in shallower water during the late Miocene and subsequently subsided to today's depths. Farther upslope, Kulm et al. documented subsidence rates of 275 and $500 \mathrm{~m} / \mathrm{m} . \mathrm{y}$, for similar Lima Basin sediment sections. Even on the scale of the hand samples obtained by dredging, Kulm et al. noted that the forearc rocks became increasingly tectonized to the east toward the trench-slope break.

A large, 15-m-wide turbidite sediment pond covers much of the upper-slope region. Seismic-reflection data indicate the maximum thickness of this $400-\mathrm{km}^{2}$ turbidite pond is only about $40 \mathrm{~m}$. The surface of the turbidite pond is dominated by a network of shallow debris-flow channels that are fed from farther upslope. These channels coalesce in the pond to form a single canyon that erodes downslope where line D crosses the deeper outcrops (Plate 1).

The outcropping Lima Basin section east of the turbidite pond is much less fractured and disrupted than similar sediments below the pond. These thin, lithified, sediment outcrops are extensive along strike and are highlighted in the side-scanning image by elongated turbidite ponds trapped by the outcrops (Fig. 3).

The entire upper slope is being stripped of surface sediments, presumably in response to overall subsidence of the forearc. Except for the dendritic pattern in the extensive, but thin, turbidite pond, the sediments are descending in thin, straight, debrisflow channels. The uniformity of these channels as well as the places where outcrops offset across these channels suggest that they are controlled by faults. These apparently normal faults, which strike perpendicular to the trench axis, are small but occasionally can be seen in seismic-reflection data (Bartlett, 1987). Bartlett further hypothesized that several larger faults perpendicular to the trench axis control the overall physiography of the forearc and may also serve as conduits for deep fluids from the subduction zone.

\section{YAQUINA BASIN SURVEY}

A second SeaMARC II survey to select a drill site was conducted around $9^{\circ} \mathrm{S}$, north of where the MFZ intersects the Peru convergent margin (Fig. 1). This survey area, referred to here as the Yaquina Basin survey, is centered only $250 \mathrm{~km}$ from the Lima Basin survey and covers essentially the same structural parts of the convergent margin. However, the area shows quite a different morphology (Plate 2).

A summarized physiographic map of the Yaquina Basin survey illustrates the differences between the survey areas, as discussed next (Fig. 4).

1. Nazca Plate. The oceanic plate near $9^{\circ} \mathrm{S}$ is more faulted as it approaches the subduction zone than the plate off Lima to the south. The throws on the faults are greater and sometimes exceed $300 \mathrm{~m}$, and the fracturing is more discontinuous along the strike of the trench. In the middle of the survey one can see a large, rotated fault block, described previously by Schweller et al. (1981) and Kulm et al. (1981), which is lodged in the trench axis.

2. Trench Axis. The trench axis in this survey area north of the MFZ is wider and frequently disrupted by the larger oceanic plate fault blocks, as compared to that in the Lima Basin survey area. The depth of the trench-axis turbidite pond is about the same. Ponds of apparent trench-fill turbidites presently perch on shallower regions of the adjacent oceanic plate (i.e., between lines $\mathrm{H}$ and $\mathrm{I}$ in Plate 2). Either these ponds were elevated since formation or the trench axis has subsided to cut off the route for the trench-fill turbidites to flow onto the Nazca Plate.

3. Inner Trench Wall. Because of irregularities of the converging Nazca Plate and subsequent disruption of the trench axis, the inner trench wall shows a marked lack of lateral continuity, compared with its southern neighbor. This wall rises from the trench floor at $6200 \mathrm{~m}$ to the trench-slope break at about $4000 \mathrm{~m}$ at a slope that varied along strike between $6^{\circ}$ and $12^{\circ}$ (area 3 in the physiographic map, Fig. 4). Slump-induced mass wasting may also contribute to the variability of the width of the inner trench wall.

Thus, in contrast to the more southern survey area, considerable contribution of local slope sediments may have occurred to the trench fill in the Yaquina Basin survey area. This may contribute to the variability in back-scatter characteristics of the trench-fill pond (seen in Plate 2).

4. Midslope Basins. Landward of the trench-slope break at depths of about $4300-4400 \mathrm{~m}(10-20 \mathrm{~km}$ east of the trench axis), a series of relatively small midslope basins lies along the strike of the trench. These midslope basins seem less well developed than those encountered in the Lima Basin survey area.

5. Western Edge of the South American Continent. Landward of the midslope basins, the entire forearc is blanketed with sediment and has only occasional dark patches of apparent rock outcrops and indurated sediments, compared with that in the Lima Basin area. The most obvious dark outcrops (area 8 of Fig. 4) were dredged and yielded quartz-rich micaceous schists (Kulm et al., this volume) similar to the outcrops of Paleozoic metamorphics on the upper-slope ridge of Islas Hormigas (J. Cruzado, pers. commun., 1985).

An extensive system of debris-flow channels also covers this slope. However, these channels are less obvious in the side-scan- 


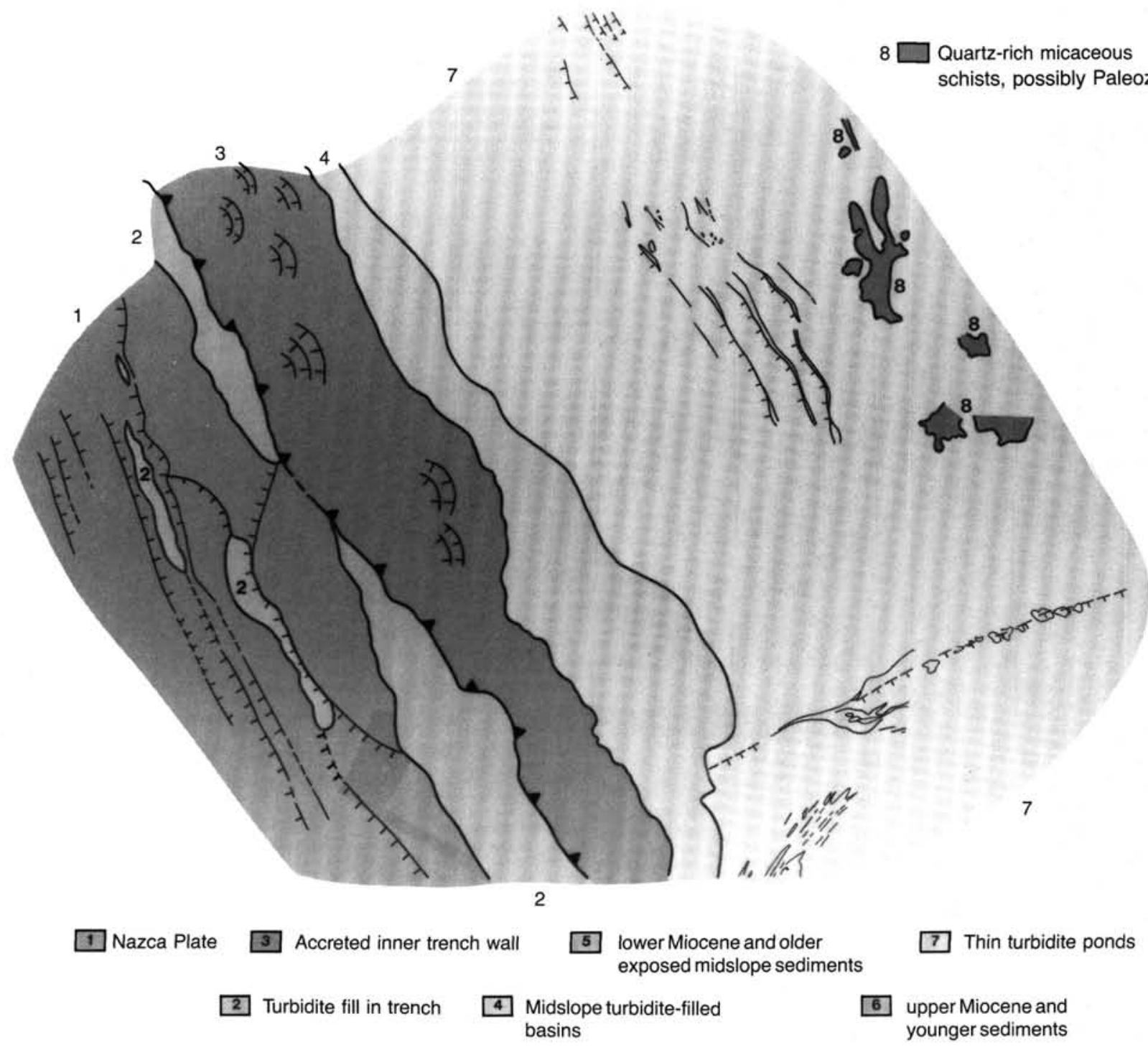

Figure 4. Generalized physiographic map of the Yaquina Basin area.

ning image than those in the Lima Basin area because they do not cut down into the reflective lithified layers. These debrisflow channels occur on slopes caused by along-strike faulting and flexure on the forearc. In the Yaquina Basin area, these channels form anastomosing patterns that run downslope in the sediment blanket, in contrast to the linear, fault-controlled debris channels in the Lima Basin area.

The landward flank of the Yaquina Basin, 50 to $60 \mathrm{~km}$ northeast of the trench axis, contains numerous scarps trending $\mathrm{N} 35^{\circ} \mathrm{W}$. These scarps are the surface expression of normal faults, as observed in multichannel seismic profiles (von Huene et al., 1985) that have throws on the order of $100 \mathrm{~m}$. The general slope of the forearc is greater below these faults, which suggests that they may represent the "hinge line" for regional vertical motions of the forearc.

A large system of debris-flow channels, interspersed with large reflective areas that resemble mud volcanoes, trends across the entire survey area perpendicular to the strike of the trench at the southeastern edge of the surveyed area. We interpreted this system as a major fault that was probably caused by "piano key" disruption of the overriding South American Plate. The descending Nazca Plate occurs at a greater depth beneath the mud volcanoes (seen in the lower right corner of Plate 2) than beneath those interpreted in the Lima Basin. The larger fault in the Yaquina Basin area could easily fracture the entire overriding plate. A dredge haul from this feature at a water depth of about $3800 \mathrm{~m}$ yielded living specimens of the vesicomyid mollusk Calyptogena, a clam depending on symbiotic chemotrophic bacteria, which provided further evidence of fluids that emanate from the seafloor (Kulm et al., this volume).

\section{DISCUSSION}

Two major features occur on the Nazca Plate in the area of these surveys: (1) the Nazca Ridge, which intersects the trench at $15^{\circ} \mathrm{S}$, and (2) the Mendana Fracture Zone, which intersects the trench at $10^{\circ} 30^{\prime} \mathrm{S}$. The Nazca Ridge is a large aseismic ridge that may be the trace of a hot spot on the spreading center during formation of the Nazca Plate. Both the Nazca Ridge and the Mendana Fracture Zone trend perpendicular to isochrons on the plate. The plate-convergence geometry along the coast of central Peru indicates that these features may sweep south along the west coast of South America.

The Lima Basin area has a small but continuous accretionary prism that is forming above a laterally continuous trench 
axis. The forearc is subsiding, and surface sediments of the upper slopes are eroding. This may simply be a response to oversteepening of the slope. The sediments eroding from the upper slopes are deposited in large, midslope turbidite basins.

The trench and lower slopes of the Yaquina Basin area are disrupted by large, irregular, basaltic ridges from the Nazca Plate. There are few laterally continuous features. The accretionary prism in the inner trench wall is similar in size to the same feature in the Lima Basin but is discontinuous along strike. The midslope basins in the Yaquina Basin area are smaller than those in the Lima Basin area. This is probably true for two reasons: (1) there are numerous discontinuities in the trench-slopebreak high in the Yaquina Basin area, which allows sediment transport from the midslope basin areas down into the trench, and (2) there is less erosion, and thus less sediment supply, from the upper slopes in the Yaquina Basin area. The upper slopes in the Yaquina Basin region are blanketed with sediments.

We suspect that the differences in the trench and the inner trench wall in both areas are a response to the different character of the subducting slab. Thus, irregularities in the surface of the Nazca Plate are disrupting the edge of the overriding plate. This effect probably was exacerbated by the recent passage of the even rougher surface of the MFZ through the Yaquina Basin area. In contrast, the more orderly structure of the inner trench wall of the Lima Basin reflects the less-disrupted plate that is being overridden. This structure also indicates that the MFZ has not yet reached this more southern part of the trench.

Differences in the upper slopes of the two survey areas may result from a larger-scale phenomenon. We suspect that the time after the passage of the Nazca Ridge through the area may have been a more significant influence. When a large feature such as the Nazca Ridge is subducted, a simplified tectonic sequence of events on the forearc may include (1) regional uplift (even to the point of causing subaerial erosion) and tectonic erosion of the leading edge of the overriding plate, followed by (2) regional subsidence, oversteepening of the mid- and upper slopes and submarine erosion, and then (3) stabilization, slope sediment deposition, and activation of a sequence of offscraping of turbidite-filled sediments and construction of an accretionary prism. The Lima Basin area may be in the second stage of recovery from passage of the Nazca Ridge, whereas the Yaquina Basin area has recovered completely and is in the third stage of this passage.

\section{REFERENCES}

Bartlett, W. A., 1987. Peru forearc sedimentation: SeaMARC II side scan interpretation of an active continental margin [M.A. thesis]. University of Hawaii, Honolulu.

Blackinton, J. G., Hussong, D. M., and Kosalos, J., 1983. First results from a combination side-scan sonar and seafloor mapping system (SeaMARC II). Proc. Offshore Technol. Conf., 4478:307-311.

Hussong, D. M., 1986. Mud volcanoes. In Yearbook of Science and Technology: New York (McGraw-Hill), 286-289.

Hussong, D. M., and Taylor, B., 1985. Peru fore-arc structure and tectonic disruption. Eos, 66(46):2096.

Hussong, D. M., and Wipperman, L. K., 1981. Vertical movement and tectonic erosion of the continental wall of the Peru-Chile Trench near $11^{\circ} 30^{\prime}$ south. Geol. Soc. Am. Mem., 154:509-524.

Hussong, D. M., and Fryer, P., 1983. Backarc seamounts and the SeaMARC II seafloor mapping system. Eos, 64(45):627-632.

Kulm, L. D., Schrader, H., Resig, J. M., Thornburg, T. M., Masias, A., and Johnson, L., 1981. Late Cenozoic carbonates on the Peru continental margin: lithostratigraphy, biostratigraphy and tectonic history. Geol. Soc. Am. Mem., 154:445-468.

Schweller, W. J., Kulm, L. D., and Prince, R. A., 1981. Tectonics, structure and sedimentary framework of the Peru-Chile Trench. Geol. Soc. Am. Mem., 154:323-350.

Thornburg, T. M., and Kulm, L. D., 1981. Sedimentary basins of the Peru continental margin: structure, stratigraphy, and Cenozoic tectonics from $6^{\circ} \mathrm{S}$ to $16^{\circ} \mathrm{S}$ latitude. Geol. Soc. Am. Mem., 154:393422.

von Huene, R., Kulm, L. D., and Miller, J., 1985. Structure of the frontal part of the Andean convergent margin. J. Geol. Res., 90(87): 5429-5442.

Ms 112A-108 